\title{
Investigation of the Effects of Maresin-1 on Testicular Ischemia Reperfusion Induced Oxidative Stress
}

\section{Ayhan Tanyeli, ${ }^{1}$ Ersen Eraslan, ${ }^{2}$ Mustafa Can Güler, ${ }^{1}$ Fazile Nur Ekinci Akdemir, ${ }^{3}$ Derya Güzel Akdoğan, ${ }^{4}$ Ömer Topdağı, ${ }^{5}$ Elif Polat ${ }^{6}$}

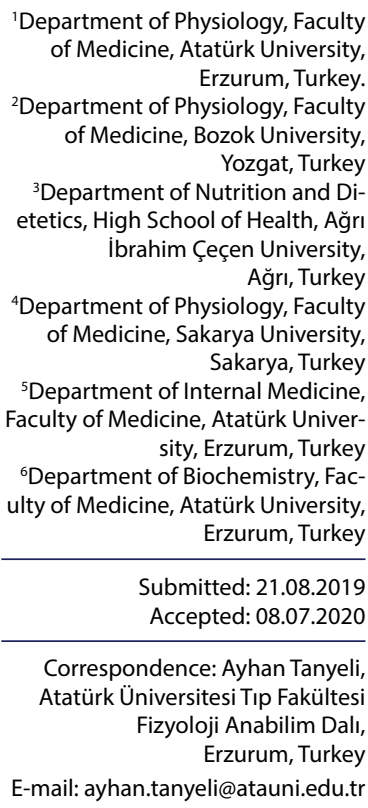

Submitted: 21.08.2019

Accepted: 08.07.2020

Correspondence: Ayhan Tanyeli, Atatürk Üniversitesi Tıp Fakültesi Fizyoloji Anabilim Dalı, Erzurum, Turkey

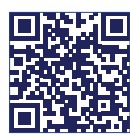

Keywords: Inflammatory; maresin I; oxidative stress; rat; testicular ischemia reperfusion.

\section{ABSTRACT}

Objective: The purpose of this study is to examine the protective effects of maresin I on testicular injury induced by ischemia reperfusion.

Methods: 24 Sprague-Dawley male rats were divided into 3 groups. The groups are planned as follows; sham, ischemia reperfusion and ischemia reperfusion+maresin I groups. The spermatic cord was detected and clamped for 2 hours to establish the prompt. After 2 hours, the clamp was removed and testicular reperfusion was achieved for 2 hours. At the end of the reperfusion phase, testicular tissues were taken and total antioxidant capacity (TAC), total oxidant capacity (TOC), superoxide dismutase (SOD), malondialdehyde (MDA) and myeloperoxidase (MPO) levels were determined by spectrophotometric method.

Results: In the ischemia-reperfusion group, TOS and MDA and MPO are increased, the levels of TAS and SOD molecules are decreased. TOS and SOD levels are increased and TAS, MDA and MPO levels are decreased in the Maresin-I treatment group.

Conclusion: These results show us that a single dose of maresin-I application is effective against oxidative damage caused by ischemia reperfusion.

\section{INTRODUCTION}

Testicular torsion is an acute surgical condition that can result in ischemia, severe destruction of the testis and ischemia, and even infertility. ${ }^{\left[{ }^{[}\right]}$It has been shown in the literature that oxidative stress is also responsible for the damage caused by detorsion after ischemia. ${ }^{[2]}$ Molecules migrating to the ischemic area with greater blood flow after deformation lead to ischemia reperfusion (I/R) damage of the testis. Superoxide anions, hydrogen peroxide and hydroxyl radicals lead to the formation of reactive oxygen radical (ROS) and damage many components of the cell, especially the cell membrane and DNA. ${ }^{[3]}$ Changes in blood supply by $\mathrm{I} / \mathrm{R}$, excessive ROS secretion, cytokine and neutrophil migration cause changes that may lead to infertility ${ }^{[4]}$ In rats, spermatic cord torsion causes apoptosis and inflammation-mediated damage to spermatogenesis. ${ }^{[5]}$ Antioxidant agents used today reduce the damage 
by eliminating ROS in addition to the body's endogenous antioxidant defense mechanisms. ${ }^{[6,7]}$

Maresin-I (MaR-I) (7,I4-dihydroxydocosa-4Z, 8Z, 10, I2, 16Z, 19Z hexanoic acid) is derived from docosahexaenoic acid. ${ }^{[8]} \mathrm{MaR}-\mathrm{I}$ is a chemical isomer of maresin. It shows that MaR-I inhibits ROS in cells and tissues and alleviates the inflammatory response. It was also found to suppress colonic inflammation in mice. ${ }^{[9,10]} \mathrm{MaR}-\mathrm{I}$ has been shown to be an effective mediator in the stopping of polymorphonuclear infiltration and phagocytosis of macrophages. [II] MaR-Idecreased liver steatosis in ob/ob and dietary obese mice. ${ }^{[2]}$ MaR-I also improved microbial killing via macrophages in clinical periodontitis. ${ }^{[13,14]}$ MaR-I demonstrated anti-inflammatory effects in a murine colitis model.

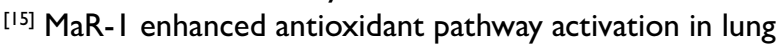
I/R injury. ${ }^{[16]}$ Here, it was evaluated the effects of MaR-I against oxidant and inflammatory injuries in testicular T/D rat model.

\section{MATERIALS AND METHODS}

Experimental phase of current research was carried out at Experimental Animal Research and Application Center in our university and experiment animals were supplied by the same place. Animals were kept into standard cages in laboratory environment provided with humidity, temperature and light/dark cycle control. Animals were fed with standard pellet feed and water. Animals were fasted before the experiment for 12 hours to prevent anesthesia complications. This study was initiated with approval (2019-65) of our University Experimental Animals Local Ethics Committee. Maresin-I was supplied by Sigma-Aldrich Co, USA.

\section{Groups and I/R model}

In our study, 24 Sprague-Dawley male rats were weighed $(270 \pm 15 \mathrm{~g})$ and randomly divided into 3 groups. In sham group, the abdominal area was shaved and cleaned. Also, abdominal area was opened with an incision under the anesthesia and closed again without $\mathrm{I} / \mathrm{R}$ model and any medication. In I/R group, immediately after anesthesia was given, the rats were fixed in the dorsal horizontal position. The incision area was cleaned with povidone iodine. Median laparotomy incision was made in $\mathrm{I}-2 \mathrm{~cm}$ size. Spermatic cord was found and clamped with atraumatic microvascular clamp to create ischemia for 2 hours. The clamp was removed and testis reperfusion allowed for 2 hours. At the end of the reperfusion period, testis tissue samples were rapidly taken. $I / R+M a R-I(I \mathrm{ng} / 0.1 \mathrm{~mL})$; as a defined in the I/R group, ischemia was induced for 2 hours by clamping. MaRI (diluted in sterile saline) was administered intraperitoneally at dose of $1 \mathrm{ng} / 0.1 \mathrm{~mL} 30 \mathrm{~min}$ utes before reperfusion. ${ }^{\left[{ }^{17]}\right]}$ After 2 hours of ischemia, the clamp was removed and the reperfusion period started for 2 hours. Finally, at the end of the experiment, testes were washed and kept frozen until the biochemical analysis.

\section{Biochemical measurements}

Testis tissues were taken out of the deep freeze and weighed on the day of the analysis. A 10\% homogenate was created by adding phosphate buffer on the tissues and they were homogenized (IKA, Germany) at 12.000 rpm for $\mathrm{I}-2 \mathrm{~min}$ on ice. Homogenate tissue samples were centrifuged at $5000 \mathrm{rpm}$ at $+4^{\circ} \mathrm{C}$ for $30 \mathrm{~min}$ to obtain the supernatant. Obtained supernatants were tested for TAS, TOS, SOD, MDA, MPO. After the tissues were homogenized, all biochemical analyses were carried out in supernatants from homogenized tissues. Testis samples were processed for malondialdehyde (MDA) assay to determine lipid peroxidation status according to methods of Ohkawa et al. ${ }^{[18]}$ The results were given in $\mu \mathrm{mol} / \mathrm{g}$ protein. It was measured using the superoxide dismutase (SOD) activity determination protocol defined by Sun et al. ${ }^{[19]}$ The results of tissue samples were presented in $U / \mathrm{mg}$ protein. We also quantified testis injury by measuring tissue myeloperoxidase (MPO) activity, the activity of infiltrated neutrophils, using a protocol developed by Bradley et al. ${ }^{[20]}$ The results of MPO activity tissue samples were given in $\mathrm{U} / \mathrm{g}$ protein. Total antioxidant status (TAS) value was measured with the commercially available kit (LOT: AKI708IA) Rel Assay Diagnostics, Gaziantep, Turkey). Total oxidant status (TOS) measurement was made with commercially available kit (Rel Assay Diagnostics). TAS and TOS results were presented as $\mathrm{nmol} / \mathrm{L}$. The ratio of TOS to TAS was accepted as the oxidative stress index (OSI). OSI value was detected as follows: OSI $=\left[\left(T O S, \mu \mathrm{mol} \mathrm{H}_{2} \mathrm{O}_{2}\right.\right.$ equivalent/L)/ (TAS, $\mathrm{mmol}$ Trolox equivalent $/ \mathrm{L}) \times 10]$.

\section{Statistical analysis}

One-way ANOVA with the Tukey test was used for multiple comparisons. Descriptive statistic was given as the mean \pm standard deviation (SD). The results were considered statistically significant at the level of $p<0.05$.

\section{RESULTS}

\section{Biochemical parameters}

There was no morbidity or mortality in rats during experimental applications. In Table I, when I/R group, compared to sham group, TAS (from $1.23 \pm 0.06$ to $0.67 \pm 0.12$, $p<0.00$ I) level decreased, whereas TOS (from $7.50 \pm 0.89$ to $11.96 \pm 1.04, p<0.00 I$ ) and OSI (from $0.61 \pm 0.08$ to $1.84 \pm 0.46, p<0.001$ ) levels increased. When $I / R+M a R-I$ group, compared to I/R group, TAS (from $0.67 \pm 0.12$ to $1.16 \pm 0.13, p<0.001$ ) level increased, while TOS (from $11.96 \pm 1.04$ to $7.80 \pm 0.84, \quad p<0.00 \mathrm{I}$ ) and OSI (from $1.84 \pm 0.46$ to $0.67 \pm 0.09, p<0.001$ ) levels decreased. When $\mathrm{I} / \mathrm{R}$ group compared to sham group, SOD (from $359.97 \pm 67.2 \mathrm{I}$ to $168.79 \pm 19.79, \mathrm{p}<0.00 \mathrm{I}$ ) level decreased, but MPO (from $34717.30 \pm 8438.67$ to $83419.38 \pm 9466.95$, $\mathrm{p}<0.00 \mathrm{I}$ ), MDA (from $223.99 \pm 27.87$ to $412.14 \pm 74.02$, $p<0.001$ ) levels increased. When $I / R+M a R-I$ group 
Table I. Mean values of TAS, TOS, OSI, SOD, MPO and MDA parameters and comparison among sham, I/R and I/R+MaR-I groups

\begin{tabular}{|c|c|c|c|c|c|c|}
\hline $\begin{array}{l}\text { Experimental } \\
\text { Groups/Parameters }(n=8)\end{array}$ & $\begin{array}{c}\text { TAS } \\
(\mathrm{mmol} / \mathrm{L})\end{array}$ & $\begin{array}{c}\text { TOS } \\
(\mu \mathrm{mol} / \mathrm{L})\end{array}$ & $\begin{array}{c}\text { OSI } \\
\text { (arbitrary unit) }\end{array}$ & $\begin{array}{c}\text { SOD } \\
\text { (U/mg protein) }\end{array}$ & $\begin{array}{c}\text { MPO } \\
\text { (U/g protein) }\end{array}$ & $\begin{array}{c}\text { MDA } \\
\text { ( } \mu \mathrm{mol} / \mathrm{g} \text { protein) }\end{array}$ \\
\hline Sham (I) & $1.23 \pm 0.06$ & $7.50 \pm 0.89$ & $0.6 I \pm 0.08$ & $359.97 \pm 67.21$ & $347 \mid 7.30 \pm 8438.67$ & $223.99 \pm 27.87$ \\
\hline I/R (II) & $0.67 \pm 0.12^{\mathrm{a}}$ & $11.96 \pm 1.04^{\mathrm{a}}$ & $1.84 \pm 0.46^{\mathrm{a}}$ & $168.79 \pm 19.79^{a}$ & $83419.38 \pm 9466.95^{a}$ & $412.14 \pm 74.02^{\mathrm{a}}$ \\
\hline I/R+MaR-I (III) & $1.16 \pm 0.13^{b}$ & $7.80 \pm 0.84^{b}$ & $0.67 \pm 0.09^{b}$ & $379.29 \pm 45.28^{\mathrm{b}}$ & $34203.94 \pm 7711.96^{b}$ & $221.89 \pm 22.06^{b}$ \\
\hline
\end{tabular}

${ }^{a} p<0.001$ compared to sham group. ${ }^{b} p<0.001$ compared to I/R group. TAS: Total antioxidant status; TOS: Total oxidant status; OSI: oxidative stress index; SOD: Superoxide dismutase; MPO: Myeloperoxidase; MDA: Malondialdehyde.

compared to I/R group, while the level of SOD (from $168.79 \pm 19.79$ to $379.29 \pm 45.28, p<0.001$ ) increased, MPO (from $83419.38 \pm 9466.95$ to $34203.94 \pm 7711.96, p<0.001$ ) and MDA (from $4 \mathrm{I} 2.14 \pm 74.02$ to $221.89 \pm 22.06, p<0.00 \mathrm{I}$ ) levels decreased.

\section{DISCUSSION}

Testicular torsion is a disease caused by abnormal bending of the spermatic cord in young men. ${ }^{[2]}$ Surgical cure is achieved in $42 \%$ to $88 \%$ after torsion. ${ }^{[22]}$ Since germ cells in the testis are highly susceptible to oxidative damage, I/R damages seminiferous epithelium, germinal epithelium and Leydig cells and can lead to subfertility or infertility due to ROS overproduction. ${ }^{[23-25]}$ Studies in the literature confirm this result and have shown that sperm count decreases in male patients after torsion/detorsion (T/D). ${ }^{[26]} A$ series of cellular dysfunction after T/D causes damage to DNA, functional degradation and destruction of proteins and lipids. $[27,28]$ MDA indicates increased free radical formation ${ }^{[29,30]}$ and was increased by I/R in our study, which approached control values after agent administration. Protective endogenous enzymes, especially SOD, fight with the destructive effect of ROS and these molecules form TAS. ${ }^{[3]}$ In our study, TAS level and SOD were decreased in the I/R group, and this value increased again statistically with MaR-I application. The OSI, which is an indicator of oxidative stress, ${ }^{[32]}$ was increased in I/R and decreased in treatment group. MPO is determined intensively in neutrophils, and high concentration of MPO indicates neutrophil activation. ${ }^{[33]}$ MPO was increased in I/R and decreased significantly in MaR-I group.

Many MaR-I-related studies are available in the literature supporting the results of our study. In the sepsis-mouse model, MaR-I decreased ROS and improved CAT and SOD activity in mitochondria. ${ }^{[1]}$ MaR-I significantly reduced $R O S$ and induced SOD and CAT in lung I/R injury ${ }^{[16]}$ and protected carbon tetrachloride-induced liver injury. ${ }^{[34]}$ MaR-I decreased the proinflammatory cytokines and increased interleukin- 10 in lipopolysaccaride-induced lung injury models ${ }^{[35,36]}$ and decreased neutrophil infiltration and cytokines in another inflammatory respiratory experimental model. [37] In parallel with these studies, in current study, antioxidant and anti-inflammatory properties of MaR-I have been shown in testis I/R model in rats. In the I/R group, TAS and SOD decreased while MDA, MPO, TOS, OSI levels were increased and MaR-I treatment reversed these levels.
Due to current results, reduction of MDA, MPO, TOS, OSI levels in testicular I/R model in rats by MaR-I, suggesting that MaR-I alleviated I/R-induced testis injury. We assessed oxidative stress in testis tissue to evaluate the improving effect of the MaR-I in I/R-induced testis injury and observed that oxidative stress decreased with MaR-I. The fact that there is no study related with the protective effects of MaR-I in the literature review of $\mathrm{I} / \mathrm{R}$-induced testis injury model makes this study original.

Understanding cellular damage mechanisms of $I / R$ is important for planning new and effective treatment methods. I/R studies demonstrated that oxidative stress suppression can provide significant contributions to the I/R treatment. In this study, oxidative stress pathways were suppressed by MaR-I and this encourages hope in the treatment of I/R.

\section{CONCLUSIONS}

These results recommend that MaR-I may protect the testis by diminishing oxidative injury caused by I/R. We have indicated that treatment with $M a R-I$ at single dose ( I $\mathrm{ng} / 0.1 \mathrm{~mL}$ ) reduces testicular damage induced by $\mathrm{I} / \mathrm{R}$ in testis in experimental animals exposed to a T/D model. Part of the mechanisms of these protective effects of MaRI may be caused from supporting the antioxidant capacities by MaR-I. Moreover, further researches are necessary to explain the other protective mechanism on I/R-induced testicular tissue damage. Current study has its own limitations. We did not find any testis study with MaR-I to compare our experiment.

Ethics Committee Approval

Experimental Animal Ethics Committee of Atatürk University (protocol number: 28.03.2019/65).

Informed Consent

Retrospective study.

Peer-review

Internally peer-reviewed.

Authorship Contributions

Concept: T.A., E.E., G.M.C, A.E.F.N, G.D.E.; Design: T.A., E.E., G.M.C, A.E.F.N, G.D.E.; Materials: T.Ö., P.E.; Data: T.Ö., P.E.; Analysis: T.Ö., P.E.; Literature Search: T.A., E.E., G.M.C., A.E.F.N., G.D.E.; Writing: T.A., E.E., G.M.C., A.E.F.N., G.D.E.; Critical Revision: T.A., E.E., G.M.C., A.E.F.N., G.D.E. 


\section{Conflict of Interest}

\section{None declared.}

\section{REFERENCES}

1. Agarwal A, Allamaneni SS. Free radicals and male reproduction. J Indian Med Assoc 2011;109:184-7.

2. Dokmeci D, Inan M, Basaran UN, Yalcin O, Aydogdu N, Turan FN, et al. Protective effect of L-carnitine on testicular ischaemia-reperfusion injury in rats. Cell Biochem Funct 2007;25:611-8. [CrossRef]

3. Elshaari FA, Elfagih RI, Sheriff DS, Barassi IF. Oxidative and antioxidative defense system in testicular torsion/detorsion. Indian J Urol 2011;27:479-84. [CrossRef]

4. Karaguzel E, Kadihasanoglu M, Kutlu O. Mechanisms of testicular torsion and potential protective agents. Nat Rev Urol 2014;11:391-9.

5. Turner TT, Tung KS, Tomomasa H, Wilson LW. Acute testicular ischemia results in germ cell-specific apoptosis in the rat. Biol Reprod 1997;57:1267-74. [CrossRef]

6. Chandra AK, Chatterjee A, Ghosh R, Sarkar M. Vitamin E-supplementation protect chromium (VI)-induced spermatogenic and steroidogenic disorders in testicular tissues of rats. Food Chem Toxicol 2010;48:972-9. [CrossRef]

7. Conti V, Izzo V, Corbi G, Russomanno G, Manzo V, De Lise F, et al. Antioxidant Supplementation in the Treatment of Aging-Associated Diseases. Front Pharmacol.2016;7:24. [CrossRef]

8. Serhan CN, Dalli J, Karamnov S, Choi A, Park CK, Xu ZZ, et al. Macrophage proresolving mediator maresin 1 stimulates tissue regeneration and controls pain. FASEB J 2012;26:1755-65. [CrossRef]

9. Xu L, Yu Y, Sang R, Li J, Ge B, Zhang X. Protective Effects of Taraxasterol against Ethanol-Induced Liver Injury by Regulating CYP2E1/ Nrf2/HO-1 and NF-kB Signaling Pathways in Mice. Oxid Med Cell Longev 2018;2018:8284107. [CrossRef]

10. Ganguly N, Giang PH, Gupta C, Basu SK, Siddiqui I, Salunke DM, et al. Mycobacterium tuberculosis secretory proteins CFP-10, ESAT-6 and the CFP10:ESAT6 complex inhibit lipopolysaccharide-induced NF-kappaB transactivation by downregulation of reactive oxidative species (ROS) production. Immunol Cell Biol 2008;86:98-106.

11. Gu J, Luo L, Wang Q, Yan S, Lin J, Li D, et al. Maresin 1 attenuates mitochondrial dysfunction through the ALX/cAMP/ROS pathway in the cecal ligation and puncture mouse model and sepsis patients. Lab Invest 2018;98:715-33. [CrossRef]

12. Laiglesia LM, Lorente-Cebrián S, Martínez-Fernández L, Sáinz N, Prieto-Hontoria PL, Burrell MA, et al. Maresin 1 mitigates liver steatosis in ob/ob and diet-induced obese mice. Int J Obes (Lond) 2018;42:572-9. [CrossRef]

13. Wang CW, Colas RA, Dalli J, Arnardottir HH, Nguyen D, Hasturk $\mathrm{H}$, et al. Maresin 1 Biosynthesis and Proresolving Anti-infective Functions with Human-Localized Aggressive Periodontitis Leukocytes. Infect Immun 2015;84:658-65. [CrossRef]

14. Colas RA, Dalli J, Chiang N, Vlasakov I, Sanger JM, Riley IR, et al. Identification and Actions of the Maresin 1 Metabolome in Infectious Inflammation. J Immunol 2016;197:4444-52. [CrossRef]

15. Marcon R, Bento AF, Dutra RC, Bicca MA, Leite DF, Calixto JB, Maresin 1, a proresolving lipid mediator derived from omega-3 polyunsaturated fatty acids, exerts protective actions in murine models of colitis. J Immunol 2013;191:4288-98. [CrossRef]

16. Sun Q, Wu Y, Zhao F, Wang J. Maresin 1 Ameliorates Lung Ischemia/Reperfusion Injury by Suppressing Oxidative Stress via Activation of the Nrf-2-Mediated HO-1 Signaling Pathway. Oxid Med Cell Longev 2017;2017:9634803. [CrossRef]

17. Xian W, Li T, Li L, Hu L, Cao J. Maresin 1 attenuates the inflammatory response and mitochondrial damage in mice with cerebral ischemia/reperfusion in a SIRT1-dependent manner. Brain Res 2019;1711:83-90. [CrossRef]

18. Ohkawa H, Ohishi N, Yagi K. Assay for lipid peroxides in animal tissues by thiobarbituric acid reaction. Anal Biochem 1979;95:351-8.

19. Sun Y, Oberley LW, Li Y. A simple method for clinical assay of superoxide dismutase. Clin Chem 1988;34:497-500. [CrossRef]

20. Bradley PP, Priebat DA, Christensen RD, Rothstein G. Measurement of cutaneous inflammation: estimation of neutrophil content with an enzyme marker. J Invest Dermatol 1982;78:206-9. [CrossRef]

21. Pogorelić Z, Mrklić I, Jurić I, Biočić M, Furlan D. Testicular torsion in the inguinal canal in children.J Pediatr Urol 2013;9:793-7. [CrossRef]

22. Huang KH, Weng TI, Huang HY, Huang KD, Lin WC, Chen SC, et al. Honokiol attenuates torsion/detorsion-induced testicular injury in rat testis by way of suppressing endoplasmic reticulum stress-related apoptosis. Urology 2012;79:967.e5-11. [CrossRef]

23. Filho DW, Torres MA, Bordin AL, Crezcynski-Pasa TB, Boveris A. Spermatic cord torsion, reactive oxygen and nitrogen species and ischemia-reperfusion injury. Mol Aspects Med 2004;25:199-210.

24. Zhang S, Zeng Y, Qu J, Luo Y, Wang X, Li W. Endogenous EGF maintains Sertoli germ cell anchoring junction integrity and is required for early recovery from acute testicular ischemia/reperfusion injury. Reproduction 2013;145:177-89. [CrossRef]

25. Bodur A, Alver A, Kahraman C, Altay DU, İnce İ. Investigation of Nacetylcysteine on contralateral testis tissue injury by experimental testicular torsion: long-term effect. Am J Emerg Med 2016;34:1069-74.

26. Goldwasser B, Weissenberg R, Lunenfeld B, Nativ O, Many M. Semen quality and hormonal status of patients following testicular torsion. Andrologia 1984;16:239-43. [CrossRef]

27. Turkmen S, Mentese A, Karaguzel E, Karaca Y, Kucuk A, Uzun A, et al. A comparison of the effects of $\mathrm{N}$-acetylcysteine and ethyl pyruvate on experimental testicular ischemia-reperfusion injury. Fertil Steril 2012;98:626-31. [CrossRef]

28. Etensel B, Ozkisacik S, Ozkara E, Karul A, Oztan O, Yazici M, et al. Dexpanthenol attenuates lipid peroxidation and testicular damage at experimental ischemia and reperfusion injury. Pediatr Surg Int 2007;23:177-81. [CrossRef]

29. Gezici A, Ozturk H, Buyukbayram H, Ozturk H, Okur H. Effects of gabexate mesilate on ischemia-reperfusion-induced testicular injury in rats. Pediatr Surg Int 2006;22:435-41. [CrossRef]

30. Ozbek O, Altintas R, Polat A, Vardi N, Parlakpinar H, Sagir M, et al. The protective effect of apocynin on testicular ischemia-reperfusion injury. J Urol 2015;193:1417-22. [CrossRef

31. Kusano C, Ferrari C. 2008. Total antioxidant capacity: A biomarker in biomedical and nutritional studies. Journal of Cell and Molecular Biology 2008;7:5407.

32. Keith ES, Powers JJ. Effect of Phenolic Acids and Esters on Respiration and Reproduction of Bacteria in Urine. Applied Microbiology 1965;13:308-13. [CrossRef]

33. Mullane KM, Kraemer R, Smith B. Myeloperoxidase activity as a quantitative assessment of neutrophil infiltration into ischemic myocardium. J Pharmacol Methods 1985;14:157-67. [CrossRef]

34. Li R, Wang Y, Zhao E, Wu K, Li W, Shi L, et al. Maresin 1, a Proresolving Lipid Mediator, Mitigates Carbon Tetrachloride-Induced Liver Injury in Mice. Oxid Med Cell Longev 2016;2016:9203716.

35. Gong J, Liu H, Wu J, Qi H, Wu ZY, Shu HQ, et al. Maresin 1 prevents lipopolysaccharide-induced neutrophil survival and accelerates resolution of acute lung injury. Shock 2015;44:371-80. [CrossRef]

36. Gong J, Wu ZY, Qi H, Chen L, Li HB, Li B, et al. Maresin 1 mitigates LPS-induced acute lung injury in mice. $\mathrm{Br} \mathrm{J}$ Pharmacol 2014;171:3539-50. [CrossRef]

37. Nordgren TM, Bauer CD, Heires AJ, Poole JA, Wyatt TA, West WW, et al. Maresin-1 reduces airway inflammation associated with acute and repetitive exposures to organic dust. Transl Res 2015;166:57-69. [CrossRef] 
Testiküler İskemi Reperfüzyon ile İndüklenen Oksidatif Strese Maresin-1'in Etkilerinin Araştırılması

Amaç: Bu araştırmanın amacı, maresin I'in iskemi reperfüzyonun indüklediği testis hasarı üzerindeki koruyucu etkilerini incelemektir.

Gereç ve Yöntem: 24 Sprague-Dawley erkek sıçanlar 3 gruba ayrıldı. Gruplar şu şekilde planlanmıştır; sham, iskemi reperfüzyon ve iskemi reperfüzyon+ maresin I grupları. Spermatik kord tespit edildi ve istemi oluşturmak için 2 saat süre ile klempendi. İki saati takiben klemp çıkarıldı ve 2 saat boyunca testis reperfüzyonu sağlandı. Reperfüzyon aşamasının sonunda, testis dokuları alınarak total antioksidan kapasite (TAK), total oksidan kapasite (TOK), süperoksit dismütaz (SOD), malondialdehit (MDA) ve myeloperoksidaz (MPO) düzeyleri spektrofotometrik yöntemle belirlendi.

Bulgular: İskemi-reperfüzyon grubunda TOS ve MDA ve MPO arttı, TAS ve SOD moleküllerinin seviyeleri azaldı. Maresin-I tedavi grubunda TOS ve SOD düzeyleri artarken ve TAS, MDA ve MPO düzeyleri azaldı.

Sonuç: Bu sonuçlar bize, tek doz maresin-I uygulamasının, iskemi reperfüzyonunun neden olduğu oksidatif hasara karşı etkili olduğunu göstermiştir.

Anahtar Sözcükler: İnflamatuvar; maresin I; oksidatif stres; sıçan; testiküler iskemi reperfüzyon. 